\title{
Monitoring Public Participation Processes at Local Government Level: With Specific Reference to Agricultural Processes in Ntcheu District
}

\section{Z. Namondwe}

I.U Ile

School of Government, University of the Western Cape

Wilfred I. Ukpere

Department of Industrial Psychology and People Management, Faculty of Management, University of Johannesburg, Johannesburg, South Africa

E-mail:wikpere@uj.ac.za

\section{Doi:10.5901/mjss.2014.v5n4p626}

\section{Abstract}

Agriculture is the greatest source of economic development in Malawi. With decentralisation, the Ministry of Agriculture and Food security through the Department of Agriculture Extension Services sector, established the New Agricultural Extension policy to create participatory processes to address farmers' needs. This is against the background that research has shown that the more people participate in developmental issues the more their needs are prioritised, especially if the participatory structures have legal backing and are respected by stakeholders, including government officials. This research engaged the established participatory structures in agricultural processes and the extent of their efficiency. It emerged that these structured were not as effective because committees that could allow for the participation of farmers in planning and decision making at Area and District level are in fact not operational as expected.

\section{Introduction}

Participatory approaches have been the focus in in many developmental activities, in various countries, as communities strive to strengthen democratic governance across the globe. The rationale behind using participatory approaches is that when people are involved in programme decision making they will actively take part in the implementation and their needs will be addressed. Malawi is no different as government has recognized the need for more participation in various processes. If policy implementation is as intended, is the subject of this research investigation and paper. This study assesses participatory processes in the local government of Malawi in order to establish effectiveness of institutions established to promote public participation in agricultural processes and the ability for such institutions to satisfy the grassroots needs. The research question posed was; to what extent are farmers participating in agricultural decisionmaking and development processes?

This paper commences by engaging the participatory frameworks, agricultural processes in within the local government context of Malawi, where these activities take place and the impact of current practices on farmers and agriculture officers.

\section{A Historical Overview of Participatory Framework in Malawi}

The quest for participatory framework were realised prior to 1994, when Malawi was under one party political system, led by President Hastings Kamuzu Banda. In 1993, the District Focus Strategy (DFS) was adopted and changes were made to refresh participatory approaches at the local level through de-concentration (accountability of the central administrators to the central ministries (Ore, 2007:8). This initiative led to the re-organization of the Area Development Committees (ADCs) and Village Development Committees (VDCs) (Husein, 2006:373). The DFS focused on transferring decisionmaking authority to local government agencies and field structures such as, District Executive Committee (DEC), Area Executive Committee (ADC), and VDCs (Husein, 2003:274). The DFS was aimed at promoting community empowerment and to enhance capacities to mobilize resources required for community or local development. 
The establishment of the new Constitution in 1995 consolidated the creation of government authorities to promote local democratic participation as one of its responsibilities (Husein, 2003:274). A process which legitimised participatory approaches, sought to build local capacity, grassroots institutions and adequately institutionalize arenas of participation (Chinsinga 2005:530).While this was entrenched in the 1990's through the promotion of community participation in socioeconomic development, Husein (2003:273) however, argues that their origin can be traced to 1965, when District Development Committees (DDCs) and other institutions were approved to provide for participatory planning.However, despite having these policies, participation of the grassroots was not effective during the Banda era, it was highly manipulated and the local people hardly had any role in the political arena (Husein, 2003:274).

According to the Malawi Local Government Act of 1998, the District Assembly (DA) is meant to promote effective public participation in decision-making, planning and implementation of policy and developmental activities among other objectives. The Ministry of Agriculture and Food Security (2006) argues that the DA is a legitimate centre of implementation of responsibilities for Agriculture services at the local level. In 2005, the local government elections were postponed and the district assemblies in Malawi have been administering these duties in the absence of local councilors. The local councilors are meant to represent the people in the Local Assembly where decisions are made and according to the Local Government Act (1998), they are voting members in the Assembly from the political side at the local level. Furthermore, they are supposed to be involved in monitoring and provision of information to local communities about government decisions and actions and to the District Assembly about community priorities (Cammack et.al, 2007: 19).

In the absence of mandated local representatives, questions arise as to whether the institutions established for farmers to participate are achieving their intended purposes; how decisions are made without the mandated local people's representatives and voting officials in the District Assembly; and who benefits from agricultural operations at the local government level. According to Msewa (2005:73) participation by representation is one of the processes that the public are seen to have participated in decision-making in the Local Assembly in Malawi. This process assumes that the elected will represent the people's views and in that way the people are said to have participated in the decision making process. Whether farmers' views are considered in the absence of voting officials in Ntcheu District Assembly as required by legislature, is questionable.

\section{Methodology}

The research employed both qualitative and quantitative methods to collect data that would provide valid information on participatory processes in agricultural activities in Ntcheu district. Semi-structured questionnaires were used on face to face interviews with agriculture officers in Njolomole EPA and focus group discussions with farmers within eight sections in the EPA were done. Apart from the two mentioned data collection methods, other data collection methods used in this research included case study approach, literature review and observations.

Ntcheu District Assembly, has its District Agricultural Development Office at Khande, which is under Lilongwe ADD. It has Seven Extension Planning Areas namely: Njolomole, Kandeu, Bilira, Nsipe, Sharpevale, Tsangano and Manjawira. Njolomole EPA was chosen among seven EPAs and its sections cover from Nkhande (Ntcheu Agriculture District Office) , Biriwiri section to Masasa section which boarders Dedza district. The sections that were investigated are Biriwiri, Kadzakalowa, Mlangeni, Njolomole, Chilobwe, Lizulu, Mlanda and Masasa. The population was composed of ten agriculture officers responsible for operating Njolomole EPA and farmers from 202 villages in the areas of traditional authority Njolomole, Chakhumbira and Masasa. The sample population was made up of ten workers from the Agriculture Department and eight groups of farmers in villages within the EPA. Interviews with agriculture officers took place at their offices while six extension workers or Area Extension Development Officers (AEDOs) were interviewed in their various homes because they do not have offices. Farmers were also interviewed in a focus group discussion. The results obtained are discussed under the following sub-headings.

\section{Nature of Public Participation in Local Government of Malawi}

The decentralization policy and the Local Government Act of 1998 give the citizens of Malawi the right to participate in different ways in matters that affect their lives. According to Chinsinga (2005:529), Malawi adopted democratic decentralisation in order to bring the government closer to the grassroots thereby making it more responsive, accountable and representative. The people in Malawi therefore, participate through being represented in the District Assembly and being physically involved in planning and implementation of projects. Participation is done through elections of political leaders countrywide and in ensuring that the leaders elected are serving as expected (Dambala, 
2003:62). Citizens are expected to participate in the implementation of projects which include; building of schools, hospitals, roads, boreholes and other developments at the district level through contributing materially, labour, supervise or monitor the projects and report to the assembly (Ministry of Local Government and Rural Development 2005:41).

In terms of planning, the Ministry of Local Government and Rural Development(2005:41) indicated that at the district level, the district development planning system was developed to ensure that planning is a participatory process and works from the bottom upwards. It starts with Village Action Plans in which villagers are asked to define their most urgent development needs, prioritise them and suggest solutions, which are then included in the District Development Plans. Within the current decentralisation framework, Ntcheu designated as a District Assembly with thirty wards is supposed to be represented by a councilor who is supposed to present the social and economic development interests of her/ his ward to the District Assembly there by coordinating and supervising the planning and management of district development projects (Government of Malawi, 2008:4). However, this has not been possible because since 2005, the District Assemblies have been operating without councilors and this has compromised their roles in society. The District Executive Committee, which is supposed to report to the DA, has now complete control of the operations at the district level.

Structures like District Executive Committee, District Development Committee, Area Development Committee, Village Development Committee are meant to allow participation of the citizens in planning and decision- making so that programs established should address the peoples' problems. Research by Samuels, Sibale and Selvester (2009) has shown that due to lack of resources the ADCs and VDCs are unable to ensure that communities can participate in planning and programme implementation. The findings from Njolomole Extension Planning Area, indicates that knowledge of the structures among farmers interviewed is low. Most people at the grassroots are not aware of the use of participatory structures and therefore do not use them. It therefore important to conclude that despite availability of the structures, they are not effective because they do not allow the grassroots to participate in planning and decision-making. The fact that some farmers do not know them means they do not use them.

\section{Participation in Agricultural Processes in the Local Government of Malawi}

Agriculture contributes to the overall economic growth of Malawi, about $40 \%$ of the GDP, accounts for more than $90 \%$ of export earnings, offers employment to more than $80 \%$ of the population and supplies over $90 \%$ of the food consumption in the country (Ministry of Agriculture and Food Security, 2006:1). Prior to 1993, agriculture development in Malawi flourished because Agricultural Development and Marketing Corporation (ADMARC), a parastatal organisation, dominated agricultural services. ADMARC had a role of supplying inputs and providing marketing and extension services to farmers (Chinsinga \& Cabral, 2010). Due to political changes in the country, the role of ADMARC diminished and the public sector took over the control of agricultural processes in the country.

The decentralisation policy led to the establishment of the agriculture extension policy with its aim to empower local level stakeholders to participate more effectively in decision-making, programme development and implementation. The policy allows for the participation of many players in addressing extension services using various methods, promoting participatory planning and implementation of agricultural extension services through its focus in pluralism, demand driven service provision and decentralised coordination (MAFS, 2006:2). The New Extension Agriculture Policy was developed to devolve the powers and control to local farmers. Structures were established for individual farmers to find extension workers to request services and forums created to specify extension priorities and hold service to account for meeting farmers' requests (Chinsinga \& Cabral, 2010). Therefore, District Agriculture Development Offices (DADOs) were created in 28 districts of Malawi in order to make the district a focal point for planning and service delivery. DADOs were, further divided into 154 Extension Planning Areas (EPAs) and Sections. Agriculture Extension Development Executive Coordinator coordinates the EPAs and the Agriculture Extension Development Officer oversees the sections.

The District Assemblies were established as legitimate centres of implementation of responsibilities for agriculture services at the local level, with the aim of improving efficiency, effectiveness and equity of development interventions, as well as promoting local participation and democracy (Chinsinga\& Cabral, 2010). The Ministry of Agriculture and Food Security plays a role of policy formulation, coordination, facilitation and regulation of different players' activities at the local level (Chinsinga \& Cabral, 2010).

\section{Participatory Processes in Agricultural Activities and Challenges in Ntcheu District}

Considering that the sections are centres of planning and service delivery for agricultural activities for the grassroots, the 
Ministry of Agriculture and Food Security through the Department of Agriculture Extension Services (DAES) developed District Agriculture Extension Services System (DAESS) to accommodate decentralisation concerns with reference to agriculture extension services at district level (Kaarhus \&Nyirenda, 2006:19). The DAESS was developed in order to organise farmer's demands, facilitate service provider response, co-ordinate and develop agricultural strategy, and acquire funding. The DAESS structure has these forums namely District Executive Committee (DEC), District Agriculture Sub Committee (DAC), District Agriculture Extension Coordinating Committee (DAECC), District Stakeholder Panel (DSP), Area Stakeholder Panel (ASP) and Model Village (MV).

These forums/committees were established to provide a platform for the various stakeholders to meet and discuss agricultural related issues at various levels in order to promote stakeholder participation (MAFS, 2006:5). The duty to facilitate and establish such institutions rests in the hands of the District Agriculture Development Officer with the support from the District Commissioner (MAFS, 2006:5). According to the Ministry of Agriculture and Food Security (2006:1), the District Assembly oversees agricultural extension service provision through the DAC. DSP reports directly to the DAC however, the DADO is supposed to brief the DEC regularly on the progress. Farmers' demands are passed on to the DSP through ASP while other development issues are sent to the District Assembly through Area Development Committee. Currently in Ntcheu district, the DEC is the ultimate decision maker at the district level because it reports directly to the ministry of Agriculture and not to the District Assembly. This is a threat to the Local Government Act and decentralisation policy because local priorities are somehow sidelined and there are signs of recentralisation due to the priorities made by the committee on programmes that are implemented in the district.

For instance, Chinsinga and Cabral (2010), indicated that the farm input subsidy policy introduced in 2005 by the government is largely a centrally driven initiative, which is quite demanding to local staff and local resources at the expense of routine activities including extension services, water and soils conservation as well as other locally defined priorities. Aagriculture officers and farmers in an interview that most programmes introduced in Njolomole EPA follow topdown structure and directives from above giving farm input subsidy programme as an example. Farmers admitted that decisions are made without consulting them and programmes are imposed. Despite not having the chance to participate in decision-making, farmers implemented the subsidy programme.

The research established that participation of farmers increase in programmes that are well explained and have a known impact than programmes that are imposed on them. Furthermore, councilors are important to ensure prioritization of local people's needs. Their absence since May 2005 explains implementation of programmes initiated by the central government sidelining local people's priorities.

Participation of farmers in Area Stakeholder Panel is not effective in Njolomole EPA. ASPs were formed because agricultural issues were sidelined in the Area Development Committee and were to allow farmers to take part in decisionmaking and help them to demand quality services. Extension workers admitted that they had met once three months before the interview although they agreed to be meeting once every month while farmers are not aware of the forum. This means that the ASP structure has not been functioning and farmers do not yet know its purpose. Clapper (1996:73) noted that most participatory structures lack representativeness of majority beneficiaries but it is dominated by small elite group. This therefore hampers participation of citizens in participatory structures and farmers' participation is affected in this case. Furthermore, considering that the composition of ASP is similar to that of DSP, and that ASP is formed at every ADC, agriculture officers may decide to neglect forming the ASP and using DSP instead.

According to the Ministry of Agriculture (2004:7), Model Village is the centre of all activities. It is where Participatory Rural Appraisal (PRA) (Road to progress) exercise is administered. The Area Executive Development Officers facilitate the articulation of farmer demands at village level. In any participatory processes, certain procedures are followed to ensure service delivery, accountability and participatory planning (Mac Laverty, 2002:4). In participatory planning participants are supposed to be aware of the issues to be discussed and be able to contribute where necessary. It was established that participation of farmers varies in different sections and it depends on active participation of village headmen/women in the committees, farmers interests in the committees, the theme of the day. Creighton (2005:7) indicated that for participation to take place, organised procedures must be put in place for the public and officials to engage in productive discussion. He further argues that the value of participation lies in the fact that participants must be aware of the issue before participation and the impact of them to participate. Therefore, participation of farmers in meetings with Agriculture Extension Development Officers, ability to demand a service in discussion and implementation of agricultural services also depends on the farmers' knowledge of the agenda of the meetings, the day of the meeting and briefing and explanation of the service to be implemented.

According to Government of Malawi (2008:18), the number of extension workers has always been less than requirement and this has led to having high ratios of extension worker to farmer at grassroots level. Most extension 
workers are men. The ministry is therefore trying to recruit more female AEDOs through on job training programme. The Department of Agriculture is also trying to use different methodologies that can show impact to all farmers like use of Model Village approach, farmer-to-farmer extension, use of clusters, and village demonstrations open days in order to cater for low capacity of extension workers. According to farmers, lack of monitoring of projects in Njolomole EPA is also a problem, resources are not enough to support the programme and address the people's needs, lack of incentives for Agriculture Development Officers for instance, they are given 80 kwacha per month (an equivalent of three Rands) as maintenance fee. According to the District Agriculture Development Officer, the Agriculture Sector Wide Approach Programme (ASWAP) is helping in pumping more resources to the programme but some resources are still lacking. Other challenges include low participation and lack of interest from farmers, illiteracy of farmers, which leads to consuming more time to demonstrate some programmes. Therefore, the district is not effective and efficient in the dissemination of services because managing the whole district with few resources is a big challenge and therefore participatory processes are compromised.

\section{Conclusion}

An assessment of participatory processes in agriculture activities in Ntcheu district was made and the results indicated that participation of farmers in agriculture processes is low because of several factors that hinder them. Furthermore, the results indicated that although District Agriculture Extension Services System has not been put into maximum use what has been implemented so far has benefited farmers, the community and agricultural officers. However, there are so many challenges affecting effective implementation of the District Agriculture Extension Services System thereby affecting farmers' participation in agricultural processes.

The research therefore recomends effective implementation of District Agriculture Extension Services System in Ntcheu district to allow farmers to participate in planning and decision making of programmes implemented in Njolomole EPA. This will be done through provision of more resources to the programme, recruitment of more extension workers, creation of awareness of stakeholder panels, creation of markets, training of farmers and reintroduction of clubs for farmers to buy farm inputs on loan basis.

\section{References}

Brynard, P. A. (1996). Realities of citizen participation: In Bekker, K. (ed.), Citizen participation in local government. Pretoria: Van Schaik.

Brynard, P. \& De Conning, C.B. (2006). Policy implementation. In Cloete, F., Wissink, H. \& De Conning, C. Improving public policy: from theory to practice. Pretoria: Van Schaik.180 - 213.

Cammack, D., Golooba-Mutebi, F., Kanyongolo, F. \& O'Neil, T. (2007). Neopatrimonial politics, decentralisation and local government: Uganda and Malawi in 2006. In Good governance, Aid modalities and poverty reduction: linkages to the Millennium development Goals and implications for Irish Aid. Working Paper 2. [Online]. Available at http://www.odi.org.uk/resources/docs/5831.pdf [2011, October 24]

Chinsinga, B. (2005). District assemblies in a fix: the perils of the politics of capacity in the political and administrative reforms in Malawi. Development Southern Africa. (22)4: 271-282. [Online] Available at http://atoz.ebsco.com.ezproxy.uwc.ac.za /titles.asp?ld=unwc\&sid=166087303\&TabID=2http: [2010, August 26]

Chinsinga, B. \& Cabral, L. (2010). The limits of decentralised governance: the case of agriculture in Malawi.Future Agriculture Consortium. [Online] Available at www.future-agriculture.org.uk. [2011, April 20]

Chiweza, A. L. (2005). Participation: reality or rhetoric in rural communities of Malawi?Tanzanet Journal. 5(1): 1-8. [Online] Available http://www.tanzanet.org/int/journal/tznetjournal_07_2005_partic_reality_rural_comm.pdf [2010, September 28]

Clapper, V.A . (1996a). Positioning citizen participation in democratic local government. In Bekker, K. (ed.), Citizen participation in local government. Pretoria: Van Schaik publishers

Creighton, J. L. (2005). The public participation handbook: making better decisions through citizen involvement. San Francisco: JosseyBass.

Dambala, G. S. (ed.). (2003). Trainers manual civic and voter education on local and general elections:[unpublished]

Geldenhuys, A. J. (1996). Analyzing democracy for local government. In Bekker, K. (ed.), Citizen participation in local government. Pretoria: Van Schaik.

Government of Malawi. (2004). The Constitution of the Republic of Malawi. Zomba: Government Printer.

Government of Malawi. (2008). Ntcheu District Socio-Economic Profile. Ntcheu: District Assembly.

Hussein, M. K. (2003). The role of Malawian local government in community development. Development Southern Africa. 20(1): 271282. Available at http://atoz.ebsco.com.ezproxy.uwc.ac.za/titles.asp?ld=unwc\&sid=166087303\&TabID=2 [2010, February 22]

Kaarhus, R \& Nyirenda, R. (2006). Decentralisation in the Agriculture sector in Malawi: policies, processes and community linkages. 
[Online] Available at http://www.kit.nl/portals/documents/query.ashx?RecordID=668356\&Portal=RDLG [2011, December 20]

McLaverty, P. (2002). Is public participation a good thing? In McLaverty, P. (ed.), Public participation and innovations in community governance. England: Ashgate

Ministry of Local Government and Rural Development. (2005). Guidebook on decentralization and local government in Malawi. [Online]. Available at http://www2.gtz.de/urbanet/pub/GTZ-Guidebook_on_Decentralisation-en.pdf [2011, November 08]

Ministry of Agriculture, Irrigation and Food Security. (2004). District Agricultural Extension Services System implementation guide. Lilongwe, Malawi: Department of Agricultural Extension Services.

Ministry of Agriculture and Food Security . (2006). District Agricultural Extension Services System implementation guide. Lilongwe, Malawi: Department of Agricultural Extension Services.

Ore, A. (2007). Local government and decentralization in southern Africa: Ideals and realities. In Proceedings of the Norwegian Church Aid Regional Conference on "Citizen engagement for accountable local governance". Durban, South Africa, 27-29 March 2007. Available at http://www.sarpn.org.za/documents/d0002677/NCA_conference_Governance_Mar2007.pdf [November 15, 2011]

Samuels, F., Sibale, B. \& Selvester, K. (2009). People in planning in Malawi: lessons from the APAC programme in Eastern and Southern Africa. Project briefing (18). [Online] available at http://www.odi.org.uk/resources/docs/3463.pdf [2011, October 11] 